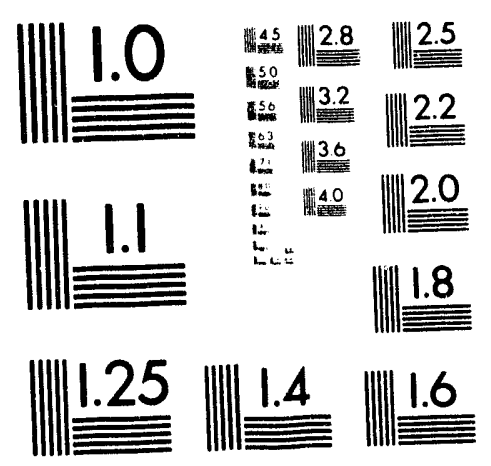



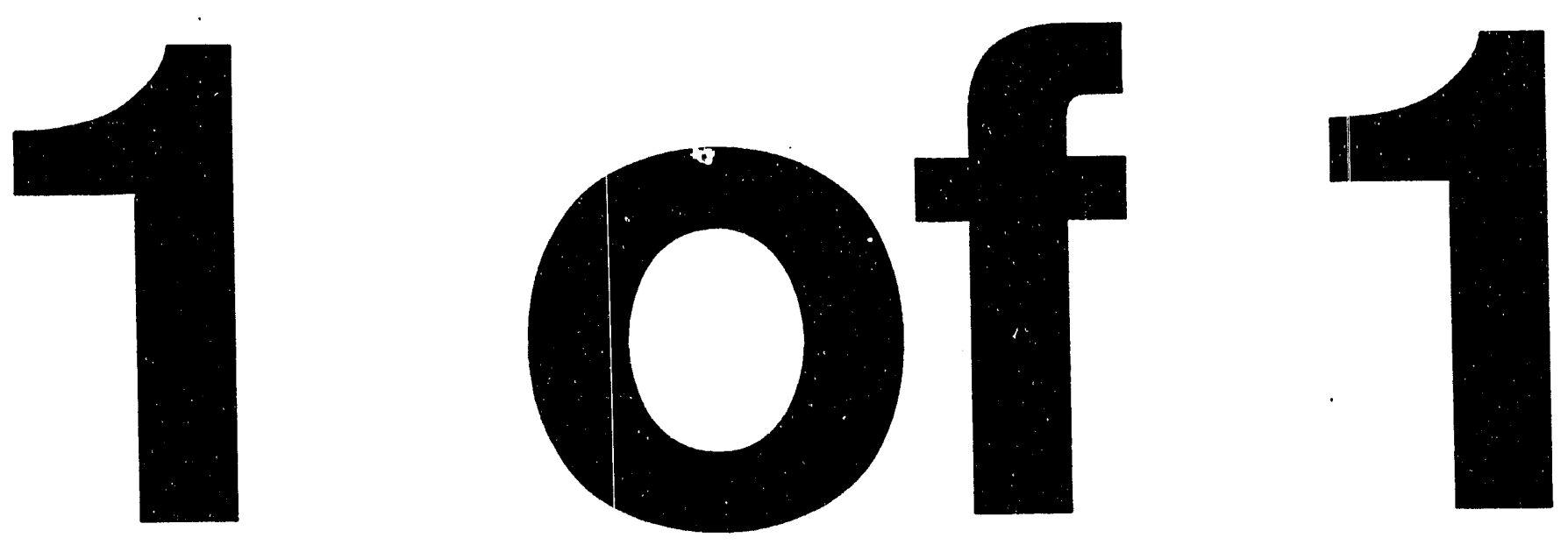


\section{Corrective Action Strategy for Single-Shell Tanks Containing Organic Chemicals}

D. A. Turner

Date Published

August 1993

Prepared for the U.S. Department of Energy Office of Environmental Restoration and Waste Management

\section{(2)} Westinghouse Hanford Company Richland, Washington 99352

Hanford Operations and Engineering Contractor for the

U.S. Department of Energy under Contract DE.AC06-87RL 10930 
WHC-EP-0671

\section{APPROVAL PAGE}

Document Title: Corrective Action Strategy for Single-Shell Tanks Containing Organic Chemicals

Approved by:

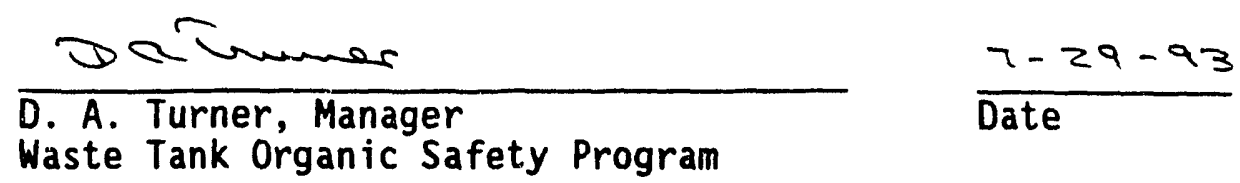




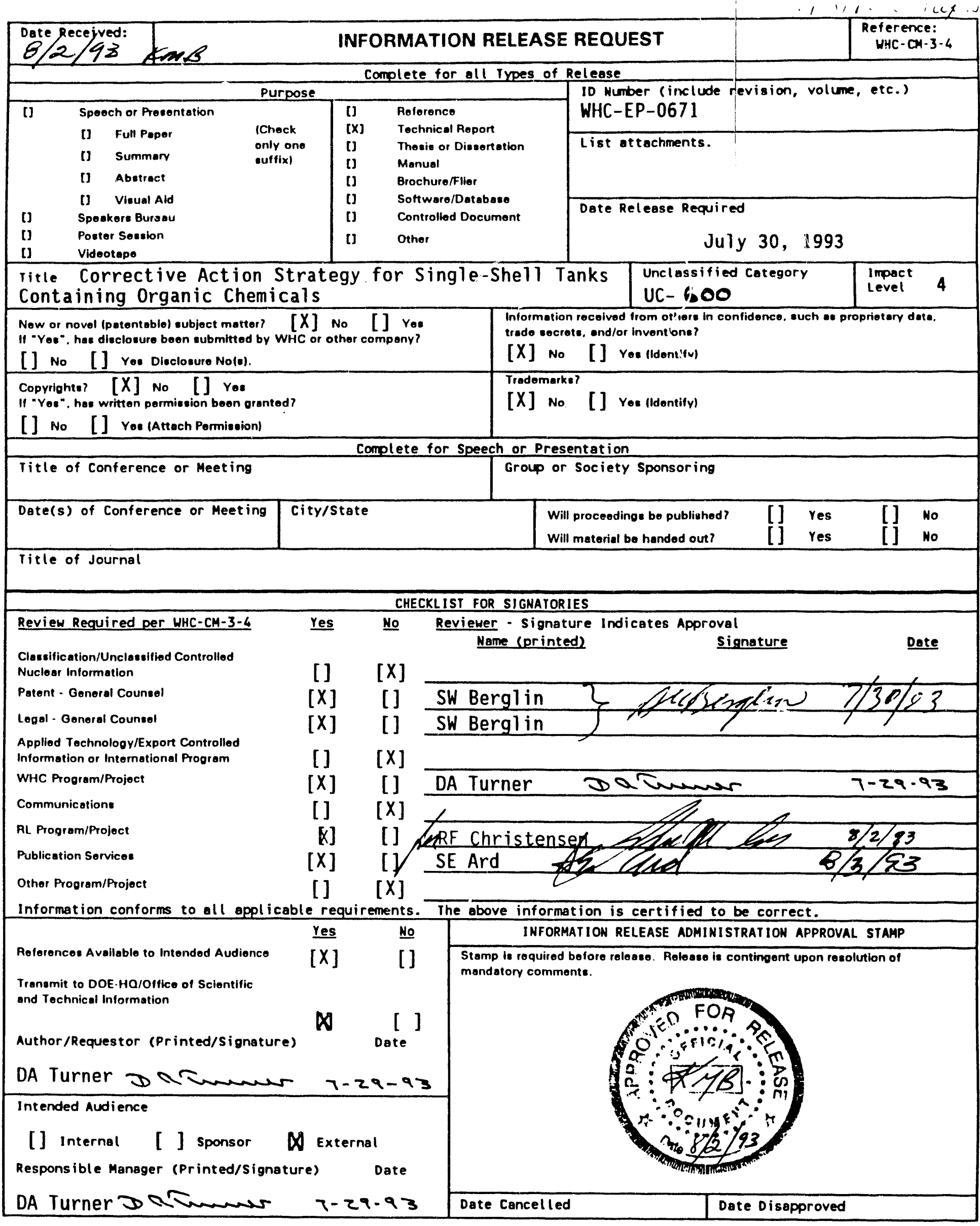


WHC-EP-0671

\section{CONTENTS}

1.0 PURPOSE ............................ . . . . . . . . .

2.0 MISSION . . . . . . . . . . . . . . . . . . . 2-1

3.0 STRATEGY . . . . . . . . . . . . . . . . . . . 3-1

4.0 APPROACH $\cdot . \cdot \cdot$.

4.1 IMPLEMENT "NO TREATMENT" OPTION (LOGIC 2.0) . . . . . . . . 4-1

4.2 IMPLEMENT MITIGATION (LOGIC 3.0) .............. . . . 4-1

4.3 IMPLEMENT REMEDIATION (LOGIC 4.0) . . . . . . . . . . . . . . 4-4

5.0 SCOPE .......................... 5-1

6.0 GOALS ......................... . . 6-1

7.0 PRIORITIES . . . . . . . . . . . . . . . . . . 7-1

8.0 DRIVERS ......................... . . . . . . .

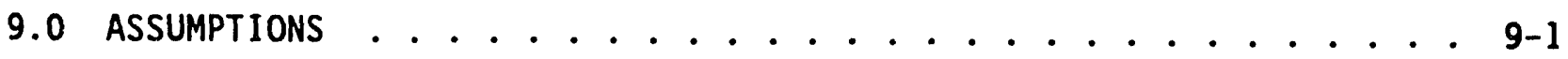

10.0 TECHNICAL BASELINE . . . . . . . . . . . . . . 10-1

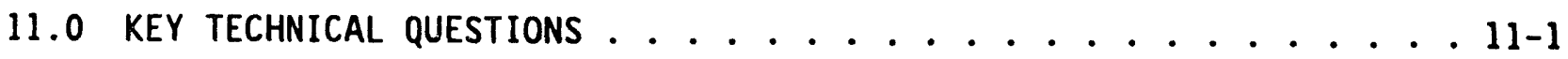

12.0 LOGIC . . . . . . . . . . . . . . . . . . . 12-1

13.0 CORRECTIVE ACTION STRATEGY . . . . . . . . . . . . . . 13-1

13.1 POTENTIAL COMBUSTION IN HEADSPACE AIR (FIGURE $13-i$ )

13.2 COMBUSTION OF ORGANIC LIQUID AS A POOL FIRE (FIGURE 13-2) . . 13-1

13.3 SURFACE FIRES IN TANKS THAT FORMERLY

HELD ORGANIC LIQUIDS (FIGURE 13-3) . . . . . . . . . . . . 13-11

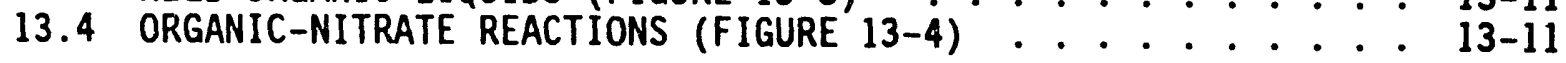

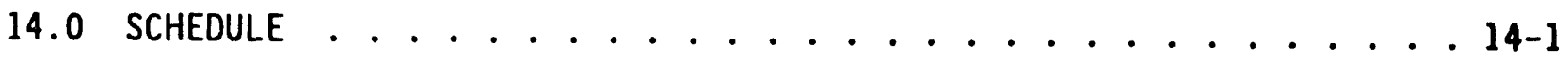

15.0 REFERENCES ....................... . . . . . . . 15

APPENDIX . . . . . . . . . . . . . . . . . . . APP-i 
WHC-EP-0671

\section{LIST OF FIGURES}

4-1 Overview of Organic Tani Safety Issue Pesolution Logic . . . . . 4-2

4-2 Approach to Organic Tanks Safety Assessment . . . . . . . . 4-3

13-1 Interim Safety Basis Document (Draft) Potential

Combustion in Headspace Air .. . . . . . . . . . . . 13-3

13-2 Interim Safety Basis Document (Draft) Combustion

of Organic Liquid as a Pool Fire ............ . . 13-5

13-3 Interim Safety Basis Document (Draft) Surface Fires

in Tanks that Formerly Held Organic Liquids . . . . . . . . 13-7

13-4 Interim Safety Basis Document (Draft)

Organic-Nitrate Reactions ................ 13-9

14-1 Waste Tank Organic Safety Program FY 1995 - 1999

Five Year Plan Milestones

\section{LIST OF TABLES}

9-1 Organic Tank Core Sampling Schedule . . . . . . . . . . . 9-3

10-1 Waste Tank Organic Safety Program Technical Baseline ...... . 10-1 


\section{LIST OF TERMS}

DOE

DREAM

EA

HQ

IPM

ISB

JCO

Program

RL

SST

TOC

USQ

WHC
Department of Energy

Data Requirements, Evaluation and Management (Project)

Environmental Assessment

Department of Energy, Headquarters

Initial Pretreatment Module

Hanford Site Tank Farm Facilities Interim Safety Basis

Justification for Continued Operations

Waste Tank Organic Safety Program

Department of Energy, Richland Operations Office

Single-Shell Tank

Total Organic Carbon

Unreviewed Safety Question

Westinghouse Hanford Company 
WHC-EP-0671

This page intentionally left blank. 


\subsection{PURPOSE}

A Waste Tank Organic Safety Program (Program) P1an is to be transmitted to the U.S. Department of Energy, Richland Operations Office (RL) for approval by December 31, 1993. In April 1993 an agreement was reached among cognizant U.S. Department of Energy - Headquarters (HQ), RL and Westinghouse Hanford Company (WHC) staff that the Program Plan would be preceeded by a "Corrective Action Strategy," which addressed selected planning elements supporting the Program Plan. The "Corrective Action Strategy" would be reviewed and consensus reached regarding the planning elements. A Program Plan reflecting this consensus would then be prepared.

This document is the "Corrective Action Strategy." It addresses, in Sections 2.0 through 14.0 that follow, selected planning elements supporting the Program Plan. Following consensus by cognizant HQ, RL, and WHC staff, these planning elements will be incorporated, along with additional detailed work scope information, into the Program Plan. 
WHC-EP-0671

This page intentionally left blank. 
WHC-EP-0671

\subsection{MISSION}

The mission of the Waste Tank Organic Safety Program is to resolve in a safe, cost-effective, and environmentally sound manner the safety issue associated with Hanford single-shell tanks (SSTs) that contain significant concentrations of organic chemicals. 


\section{WHC-EP-0671}

This page intentionally left blank. 


\subsection{STRATEGY}

The strategy fo: resolving the organic tanks safety issue is to resolve the Unreviewed Safety Question (USQ) and safety issue for tank 241-C-103 first. The floating organic layer in tank $241-C-103$ will be removed from the tank in order to mitigate the vapor and organic safety issues. Waste in the remaining seven organic tanks will be retrieved and treated as necessary for organic destruction in the Initial Pretreatment Module (IPM). This will resolve the organic safety issue for these tanks. This assumption is subject to change, depending on the outcome of technical and waste characterization studies in progress. Prior to waste retrieval, safety issue mitigation will be completed to ensure safe interim storage.

If a USQ is declared for one or more additional organic tanks, the USQs for these tanks will be resolved on a priority basis. 
WHC-EP-0671

This page intentionally left blank. 


\subsection{APPROACH}

The logic process for resolving the organic tank safety issue is illustrated in Figure 4-1. The logic process involves a problem definition phase followed by three implementation steps that lead to resolution of the safety issue for a tank or group of tanks. The implementation step followed for resolution of a safety issue is ultimately a function of whether the radioactive waste requires treatment and where the treatment takes place. If a safety issue for a tank or group of tanks can be resolved without treating the waste, logic step 2.0 (Implement "No Treatment") is followed. If resolution requires in-tank treatment (e.g., mixing, dilution, heating, etc.), logic path 3.0 (Implement Mitigation) is followed. Finally, if resolution requires out-of-tank treatment, logic path 4.0 (Implement Remediation) is followed.

The last logic path (4.0, Implement Remediation) provides a means for resolving the safety issue for tanks requiring out-of-tank resolution [i.e., retrieval to a double-she11 tank with or without treatment]. If treatment is required, it will take place in the proposed Initial Pretreatment Module (IPM). The IPM will have a special capability to destroy organics from the organic Watch List tanks at the Hanford Site.

The approach to be used for organic tanks safety assessment is shown in Figure 4-2. The approach to be used for organic tanks safety assessment (Figure 4-2) is related to the organic tank safety issue resolution logic (Figure 4-1) as described in the following sections.

\subsection{IMPLEMENT "NO TREATMENT" OPTION (LOGIC 2.0)}

This task includes two decision points that can result in three pathways. First, the results of Task 1.0 (Evaluate and Define the Problem) will be evaluated on a single tank basis (or on a group of tanks) to determine if the "No Treat....nt" Option criteria can be met. Tanks meeting these requilements will be removed from the organic tanks Watch List and the organic safoty issue will be resolved. An "inherent safety" or "passive safety" condition. as shown in Figure 4-2, will have been demonstrated.

Remaining tanks will be evaluated to determine if upgrades in monitoring equipment and safety documentation can provide assurance of continued safe storage. If so, implementation of the upgrades will lead to resolution of the safety issue for these tanks. A "Controlled Safety," condition, as shown in Figure 4-2, will have been achieved. Any tank not meeting the Criteria (even with upgrades) will then be considered for Task 3.0, Mitigation, and/or Task 4.0, Remediation.

\subsection{IMPLEMENT MITIGATION (LOGIC 3.0)}

Mitigation approaches will be identified and evaluated for technical feasibility, including safety risks, time for implementation, and effectiveness to pre-empt any identified pathways to hazards that may be 


\section{WHC-EP-0671}

Figure 4-1. Overview of Organic Tank Safety Issue Resolution Logic.

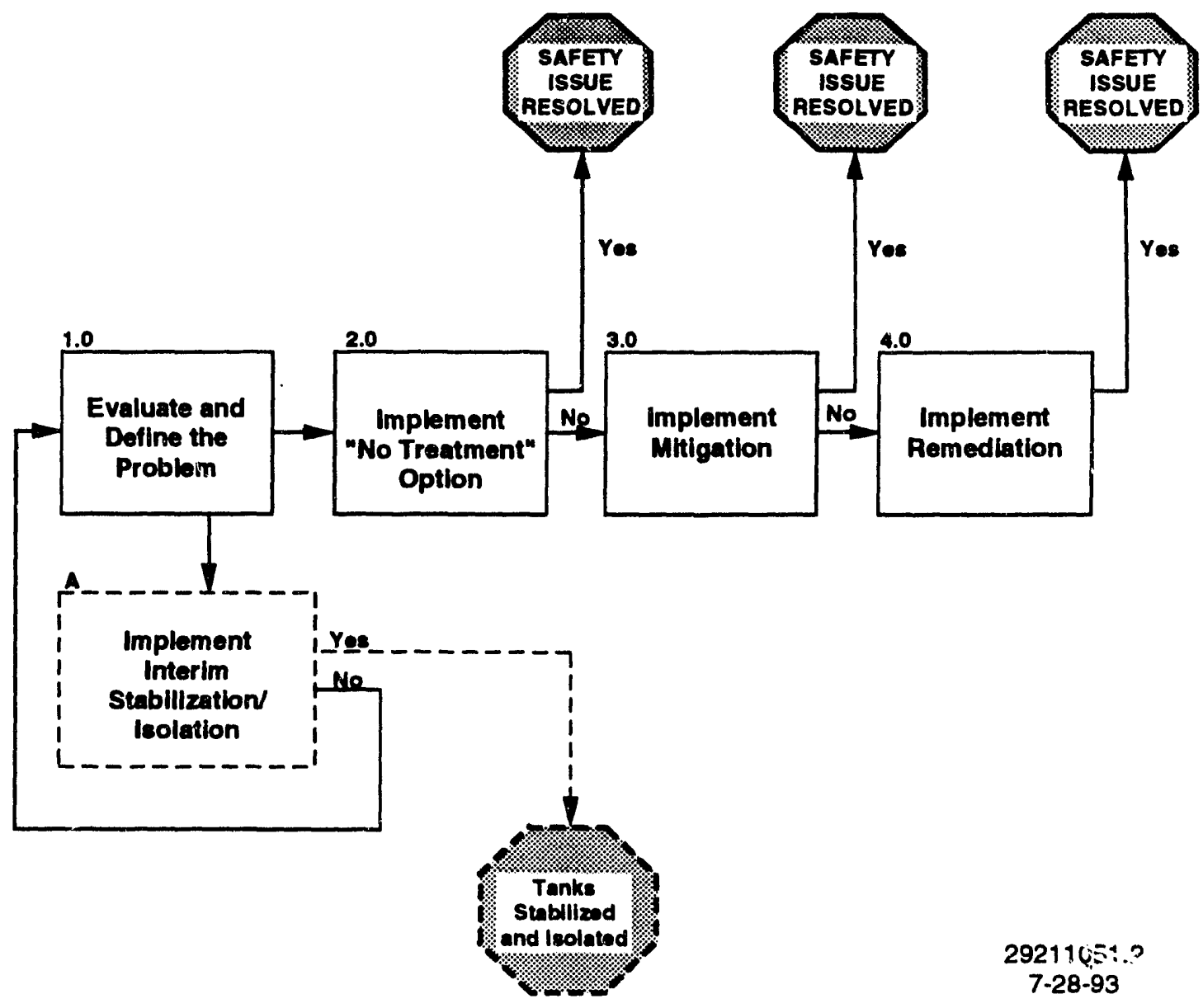


Figure 4-2. Approach to Organic Tanks Safety Assessment.

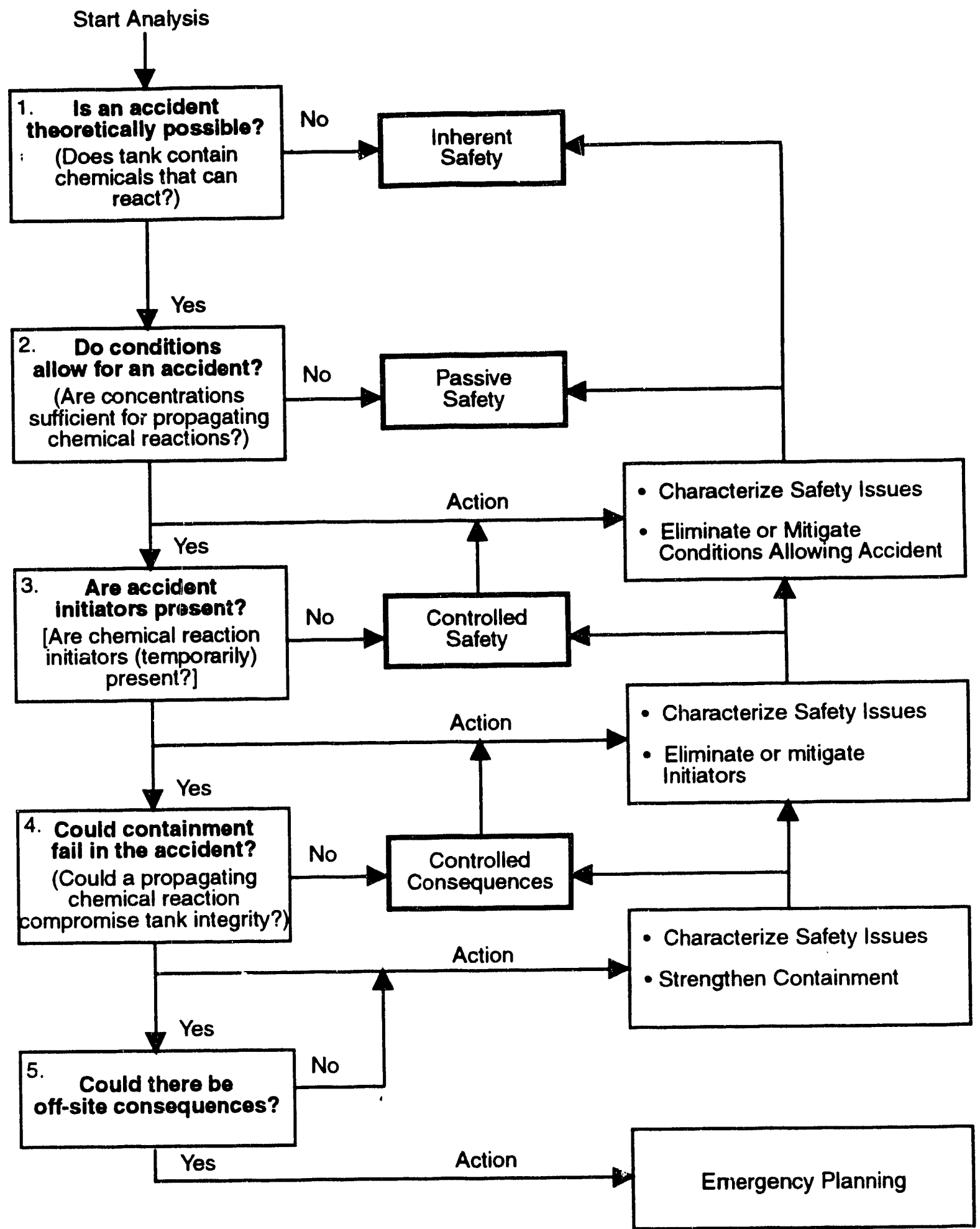


determined on a tank by tank basis. If implementing organic tank mitigation becomes a mainstream path, the most promising approach will be selected and implemented. Appropriate waste tank monitoring and control equipment will be installed and surveillance for compliance with monitoring criteria will be conducted.

The endpoint of this task is to take corrective action to mitigate (if remediation is judged to require an unacceptable time for implementation) any imminent organic tank safety concern identified for a particular tank or group of tanks while evaluating and defining the organic safety issue (Logic 1.0). Implementing mitigation would achieve a "passive safety" or "controlled safety" condition, as shown in Figure 4-2.

\subsection{IMPLEMENT REMEDIATION (LOGIC 4.0)}

Remediation may be conducted without implementing mitigation to conserve resources if any identified imminent safety concern can be resolved by remediation in a timely fashion. Alternately, remediation may follow mitigation. Implementing remediation would achieve an "inherent safety" condition, as shown in Figure 4-2. 


\subsection{SCOPE}

The Waste Tank Organic Safety Program is responsible for resolution of the organic tanks safety issue up to the time that new treatment facilities (such as the IPM) are available to implement remediation (Logic 4.0, Figure 4-1). The Program is responsible for development and installation of organic Watch List tank instrumentation for surveillance of the following conditions:

- Waste temperature

- Tank pressure*

- Waste moisture content

- Waste level.

The Program is also responsible for development and installation of equipment to control these parameters, such as modular ventilation exhauster and moisture maintenance equipment.

The Program is not responsible for long-term upgrades to organic Watch List tanks or tank farm infrastructure upgrades. Waste tank surveillance and operation of tank farm instrumentation and equipment is the responsibility of Tank Farm Operations.

The Program is responsible for identifying the organic Watch List tank characterization requirements and priorities. The Characterization Program is responsible for conducting and funding waste tank sampling and sample analysis.

The Tank Vapor Issue Resolution Program is responsible for conducting and funding vapor sampling of organic Watch List tanks.

*To determine cyclic gas releases related to organic degradation. 
WHC-EP-0671

This page intentionally left blank. 


\subsection{GOALS}

The goals of the Program are as follows:

- To resolve the organic tanks safety issue in a timely, cost-effective manner.

- To promptly resolve the tank 241-C-103 USQ (floating organic layer) and initiate work in support of the milestone to complete retrieval/disposal of the organic layer by March 31, 1996.

- To conduct a thorough assessment of the necessary and sufficient information required to resolve the organic tanks safety issue. The assessment is to employ a structured, disciplined approach and will use technical expertise on all major facets of the program.

- To develop a technically based criteria that quantifies, relative to the organic tanks safety issue:

- How well the concentration of organics in a SST must be known.

- How well the identity of individual organic constituents (functionality) must be known

- To develop a technical basis for defining an organic tanks safety envelope, including required controls, as soon as possible.

- To determine if interim stabilized organic Watch List tanks reside within the safety envelope.

- To upgrade organic tanks monitoring instrumentation and equipment to ensure compliance with safety envelope controls.

- To assess the organic tanks safety issue using historical process flowsheet and waste transfer information to the extent practical.

- To develop the Program's technical data base using actual waste samples rather than waste surrogates and/or simulants to the extent practical.

- To use technical information developed by related Waste Tank Safety Programs to the extent practical. 
WHC-EP-0671

This page intentionally left blank. 


\subsection{PRIORITIES}

Priorities for Program work activities will be determined in compliance with Section 3.3, "Priorization," of Status Report on Resolution of the Waste Tank Safety Issues at the Hanford Site (Reep 1993).

Highest priority is given to work related to USO resolution and mitigation. Therefore, Program work tasks will be prioritized as follows:

1. Resolve the USQ for tank 241-C-103 (floating organic layer).

2. Resolve the USQ for any additional organic tank(s) for which a USQ is subsequently declared.

3. Mitigate the safety issue for tank 241-C-103 by retrieving and disposing of floating organic layer.

4. Conduct appropriate safety issue mitigation activities for any additional organic tank(s) following USQ resolution.

5. Issue interim organic Watch List tank criteria.

6. Redefine the organic tanks Watch List based on interim criteria.

7. Define the safety envelope for organic Watch List tanks, including controls.

8. Upgrade tank monitoring instrumentation for organic Watch List tanks.

9. Complete an engineering study on organic Watch List tank mitigation options.

10. Assess the safety of organic Watch List tanks in interim stabilized status. 
WHC-EP-0671

This page intentionally left blank. 


\subsection{DRIVERS}

Legislative and regulatory requirements (drivers) for Program activities are described in the Appendix. The Appendix, extracted from a draft copy of Program Plan for Evaluation and Resolution of the Organic Safety Issues in Hanford Site Waste Tanks (Babad 1992), will be used to describe the legislative and regulatory requirements on Program activities. Section 2.3.4, entitled "Unreviewed Safety iuestion," will be deleted because compliance with DOE Order 5480.21, Unreviewed Safety Questions, is covered in Section 2.3.2. 
WHC-EP-0671

This page intentionally left blank.

8-2 


\subsection{ASSUMPTIONS}

The following key assumptions will be employed in developing the program plan logic and defining work tasks:

- Program work scope will comply with the work efforts recommended in the Hanford Site Tank Farm Facilities Interim Safety Basis (WHC 1993).

- Controlled parameters for ensuring safe interim storage will be those cited in the Hanford Site Tank Farm Facilities Interim Safety Basis. These are:

- Waste temperature

- Waste moisture content

- Reaction initiators (headspace deflagrations, waste "hot spots" and tank-intrusive operations).

- Tank 241-U-111 will be included on the organic tanks Watch List.

- USQs will be resolved prior to resolution of associated safety issues.

- Historical record reviews will be conducted by the Data Requirements, Evaluation and Management (DREAM) project under separate funding.

- "Vapor sampling" of SSTs will require instrumentation capable of representatively sainpling radiolytics (gases), volatiles (vapors) and aerosols. "Ccld finger" instrumentation will not be empleyed.

- Mixing of a tank's contents is not expected to be a viable safety issue mitigation option.

- Safety issue mitigation will probably be achieved by waste moisture monitoring and control.

- Safety issue mitigation (in-tank treatment) will not resolve the organic tanks safety issue, but will ensure safe interim storage.

- Safety issue resolution for seven of the eight organic Watch List tanks will be achieved by remediation (out-of-tank treatment).

- Safety issue resolution for tank 241-C-103 will be achieved by retrieval and disposal of the floating organic layer. 
- The Program will fund resolution of the organic tanks safety issue up to the time that new treatment facilities (such as the proposed Initial Pretreatment Module, Project W-236B) are available. The program will also fund instrumentation, modular ventilation exhauster and moisture monitoring and control equipment upgrades for organic Watch List tanks. Vapor sampling of organic Watch List tanks will be conducted and funded by the Tank Vapor Issue Resolution Program. Tank farm infrastructure and long-term upgrades to organic Watch List tanks will be funded by Tank Farm Upgrades, Project W-314.

- The Program will identify organic Watch List tank waste characterization requirements. The Characterization Program will conduct and fund waste tank sampling and sample analysis.

- Organic Watch List tank waste characterization will be conducted in compliance with Table 9-1.

- Safety issue resolution will be on an individual tank basis.

- Mitigation techniques that are adopted will permit subsequent waste pretreatment.

- Safety issue resolution activities will not preclude final disposal options.

- No new breakthroughs in technology are required to resolve the organic tanks safety issue. However, laboratory research is necessary to answer basic technical issues. Technology development support will be available to support efforts, as identified; research, development, demonstration, test, and evaluation funds will be available as needs are identified.

- There will be no major discoveries related to structural fitness of the waste tanks that will require an accelerated approach to close a safety issue. 
Table 9-1. Organic Tank Core Sampling Schedule.

\begin{tabular}{|c|c|c|}
\hline Priority & Tank & Date \\
\hline 1 & $241-\mathrm{C}-103 \mathrm{P}$ & FY-94 \\
\hline 2 & $241-\mathrm{B}-103 \mathrm{P}$ & FY-93 \\
\hline 3 & $241-\mathrm{U}-106 R$ & FY-94 \\
\hline 4 & $241-\mathrm{U}-111 R$ & FY-94 \\
\hline 5 & $241-U-107 R$ & FY-95 \\
\hline 6 & $241-S X-106 R$ & FY-95 \\
\hline 7 & $241-T X-105 R$ & FY-95 \\
\hline 8 & $241-T X-118 R$ & FY-96 \\
\hline 9 & $241-S-102 R$ & FY-96 \\
\hline 10 & $241-C-102 R$ & FY-97 \\
\hline 11 & $241-C-104 R$ & FY-97 \\
\hline
\end{tabular}

NOTES:

$P \quad=$ Push Mode Core Sampling

$R=$ Rotary Mode Core Sampling 
WHC-EP-0671

This page intentionally left blank. 


\subsection{TECHNICAL BASELINE}

The Program's technical baseline, in the near-term, will be based on the documents listed in Table 10-1. The majority of these documents will be generated as part of the Program's work activities during fiscal year (FY) 1994.

Table 10-1. Waste Tank Organic Safety Program Technical Baseline.

\begin{tabular}{|c|l|c|c|}
\hline No. & \multicolumn{1}{|c|}{ Document } & Document \# & Issue Date \\
\hline 1 & Waste Tank Organic Safety Program Plan & TBD & $12 / 93$ \\
\hline 2 & Interim Organic Watch List Tank Criteria & TBD & $9 / 93$ \\
\hline 3 & Safety Analysis Tank 241-C-103 & TBD & $11 / 93$ \\
\hline 4 & $\begin{array}{l}\text { Engineering Study - Retrieval/Disposal } \\
\text { Floating Organic Layer Tank 241-C-103 }\end{array}$ & TBD & $12 / 93$ \\
\hline 5 & $\begin{array}{l}\text { Fault Tree Analysis of Organic Tanks } \\
\text { Safety Issue }\end{array}$ & TBD & $9 / 94$ \\
\hline 6 & $\begin{array}{l}\text { Engineering Study - Organic Watch List } \\
\text { Tank Mitigation Options }\end{array}$ & TBD & $9 / 94$ \\
\hline 7 & $\begin{array}{l}\text { Part A Permit - Treatment of Floating } \\
\text { Organic Layer Tank 241-C-103 }\end{array}$ & TBD & $9 / 94$ \\
\hline
\end{tabular}




\section{WHC-EP-0671}

This page intentionally left blank. 


\subsection{KEY TECHNICAL QUESTIONS}

Key technical questions to be addressed by work tasks outlined in the Program Plan include the following:

- What is the necessary and sufficient set of data required to resolve the organic tanks safety issue?

- What are the chemical and physical characteristics of the waste in SSTs currently on the organic tanks Watch List?

- Is total organic carbon (TOC) a satisfactory indicator of the organic chemical inventory in an SST?

- Is an organic-nitrate/nitrite reaction in an SST a credible accident scenario? If so, what mitigation actions are technically feasible?

- What are the necessary conditions for exothermic organic-nitrate/nitrite reactivity in an SST:

- Minimum concentration of organic?

- Minimum concentration of nitrate/nitrite?

- Maximum moisture content?

- Minimum temperature to initiate a reaction?

- Minimum temperature for a propagating reaction?

- Effect of initiators/catalysts?

- What affect does waste aging have on reactivity?

- What affect do organics concentration mechanisms have on reactivity?

- Is combustion of radiolytics, volatiles, and aerosols in the head space of a SST a credible accident scenario? If so, what mitigation actions are technically feasible?

- Do organic-radionuclide concentration mechanisms exist that could lead to waste hot spots? If so, what mitigation actions are technically feasible?

- Is ignition and burning of the floating organic layer in tank 241-C-103 a credible accident scenario? If so, what mitigation options are technically feasible?

- Is ignition and burning of organic liquids adsorbed in tank 241-C-102 and 241-C-104 waste solids a credible accident scenario? If so, what mitigation actions are technically feasible?

- What information is required to develop and assess organic tank mitigation options? 


\section{WHC-EP-0671}

- How are the organics in SSTs partitioned among:

- Aqueous phase?

- Waste solids?

- Separate (floating) organic layer?

- Can organic Watch List tanks be safety interim stabilized? If so, what information is required to make the assessment? 
WHC-EP-0671

12.0 LOGIC

The logic to be used to describe Program work tasks will comply with the logic shown in Section 3.2, "Safety Issue Resolution Logic," of Status Report on Resolution of the Waste Tank Safety Issues at the Hanford Site (Reep 1993).

The Program Plan will expand this generic logic one level lower to describe Program specific detail. This level 3 logic will include a narrative description of Program activities on a task by task basis. 


\section{WHC-EP-0671}

This page intentionally left blank. 


\subsection{CORRECTIVE ACTION STRATEGY}

A Hanford Site Tank Farm Facilities Interim Safety Basis (WHC 1993) was submitted to DOE for review and comment on July 30, 1993. This document (ISB) defines the safety envelope for Hanford Site tank farms facilities and operations. As indicated in Section 9.0, "Assumptions," it is assumed that Program work tasks will be fully responsive to the work efforts recommended in the ISB.

This section presents a preliminary "corrective action strategy" for resolving the organic tanks safety issue based on the work efforts recommended in the ISB. A "corrective action strategy" logic was prepared for individual SSTS, or a group of SSTs having similar characteristics, as appropriate. Four aspects of the organic tanks safety issue are addressed in the ISB:

- SSTs with the potential for combustion in the tank's headspace

- Combustion of a floating organic layer as a pool fire

- Surface fires in tanks that formerly held floating organic layers

- SSTs with the potential for organic-nitrate reactions.

A preliminary "corrective action strategy" for each aspect of the organic tanks safety issue is presented in Figures 13-1 through 13-4.

\subsection{POTENTIAL COMBUStion IN heAdSPACE AIR (FIgURE 13-1)}

The safety concern relates to the generation of radiolytics (gases), volatiles (vapors), and aerosols that could potentially accumulate in the headspace of organic Watch List tanks in flammable concentrations.

A technical report that compares predicted and measured concentrations of tank headspace constituents will be prepared as a basis for an assessment of tank safety. If a safety issue is verified, USQ screening will be conducted. Mitigation of the safety issue will be achieved by installing and operating a tank exhauster to reduce the concentration of headspace constituents below flammable levels.

\subsection{COMBUSTION OF ORGANIC LIQUID AS A POOL FIRE (FIGURE 13-2)}

The safety concern for tank 241-C-103 (and any other SST determined to contain a significant quantity of floating organic) is the potential for ignition and combustion of the floating organic layer. Following DOE approval of the Justification for Continued Operations (JCO), dip samples of the 
WHC-EP-0671

This page intentionally left blank. 
Figure

Interim Safety Basi:
Potential Combustio
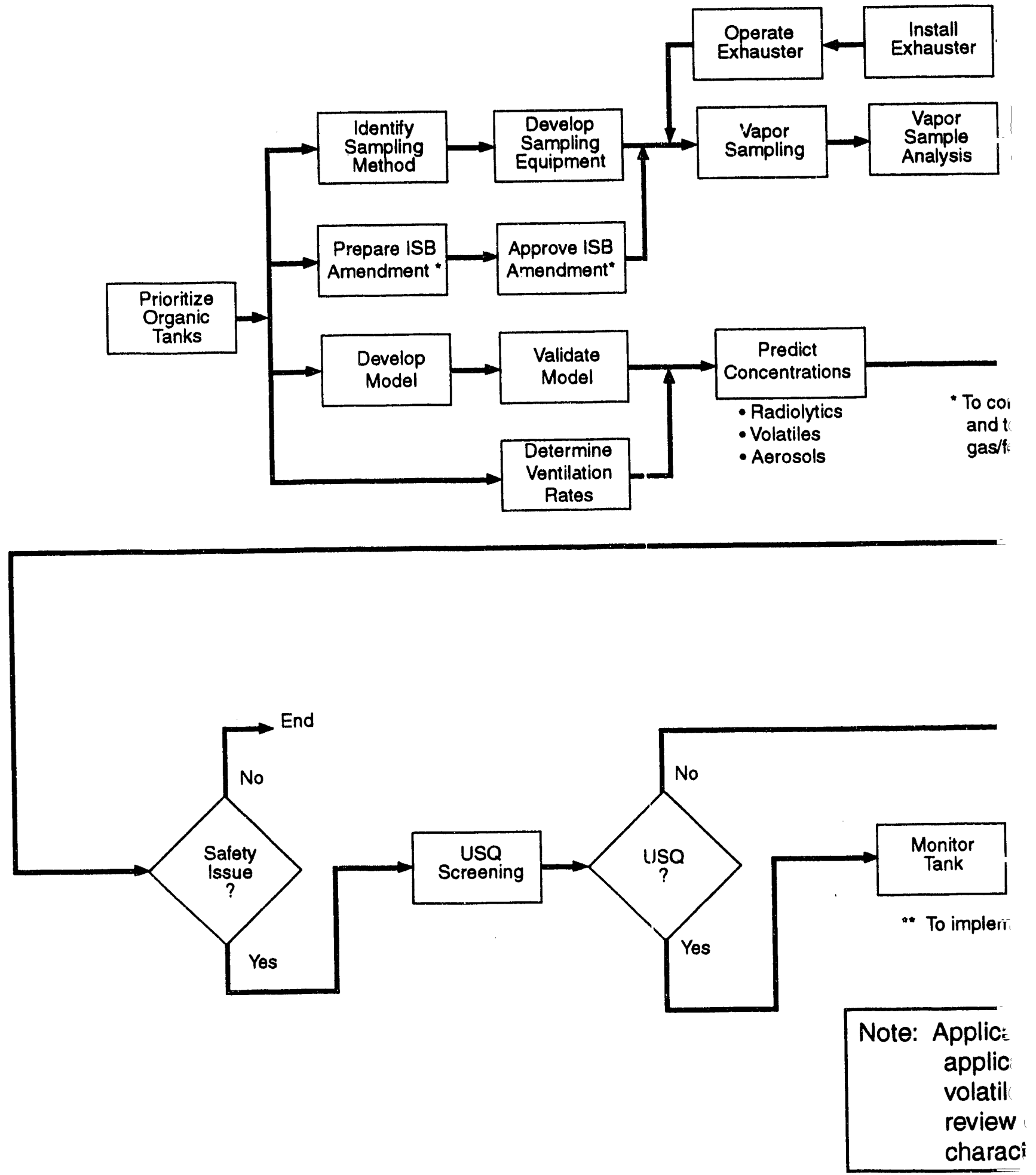


\section{3-1}

\section{Document (Draft) \\ i in Headspace Air}
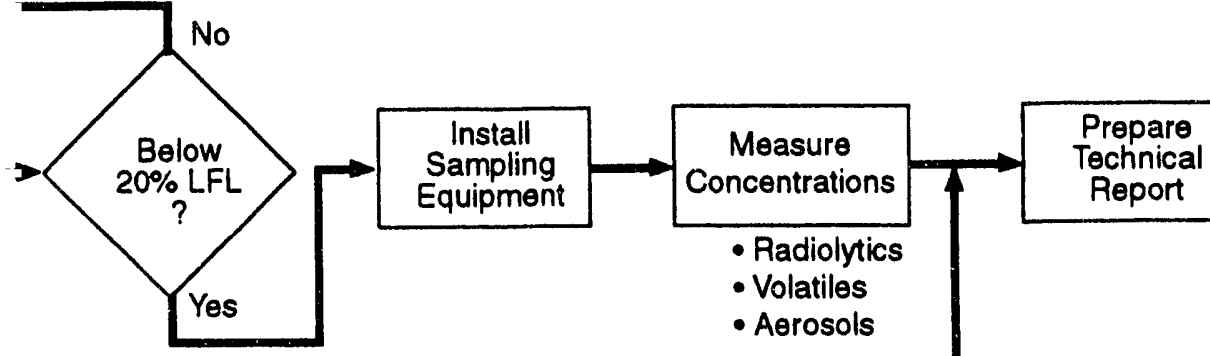

Assess

Safety

Juct vapor sampling, instalVoperate exhauster

install sampling equipment for tanks on flammable rocyanide Watch Lists

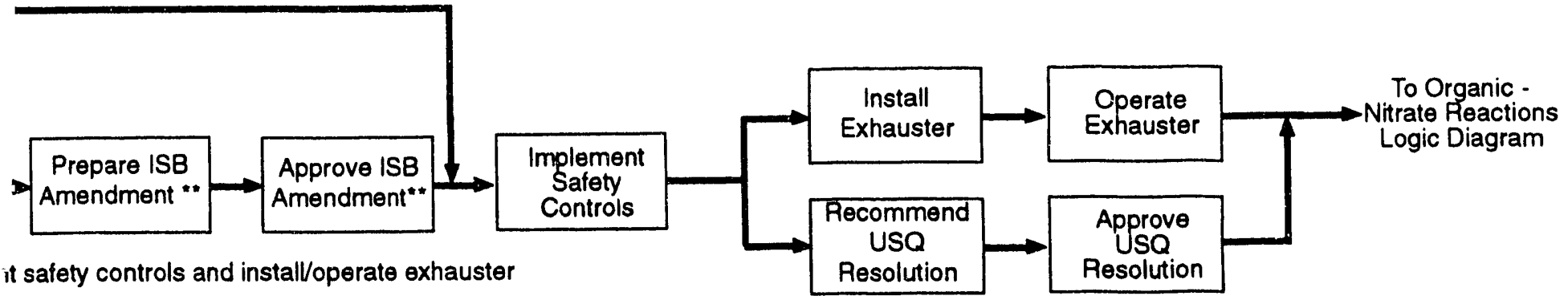

le to all organic Watch List tanks. Also

le to any SST which potentially contains radiolytics, : and aerosols in flammable concentrations, based on if historical records or newly acquired waste zrization information. 
Figı

\section{Interim Safety $\mathrm{Ba}$. Combustion of Orgar}

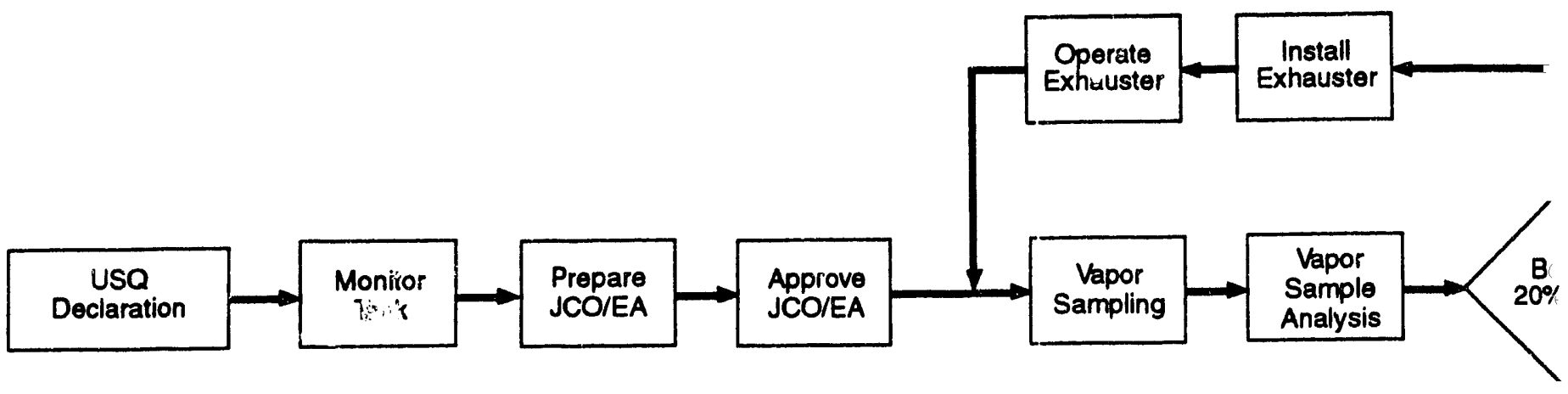

Note: Applicable to tank C-103.

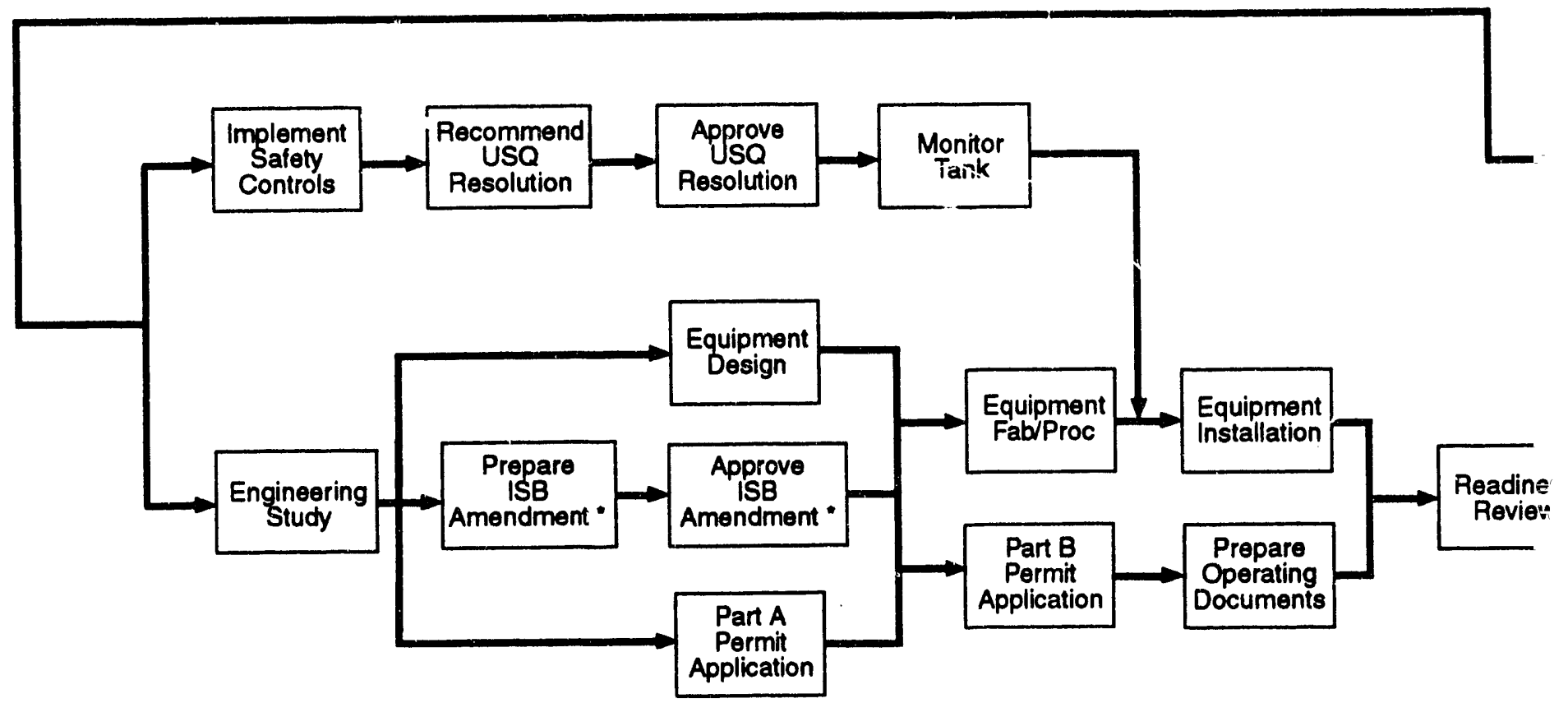

To instalVoperate organic remove
equipment and to conduct core 
re 13-2

WHC-EP-0671

is Document (Draft)

ic Liquid as a Pool Fire

No

LW
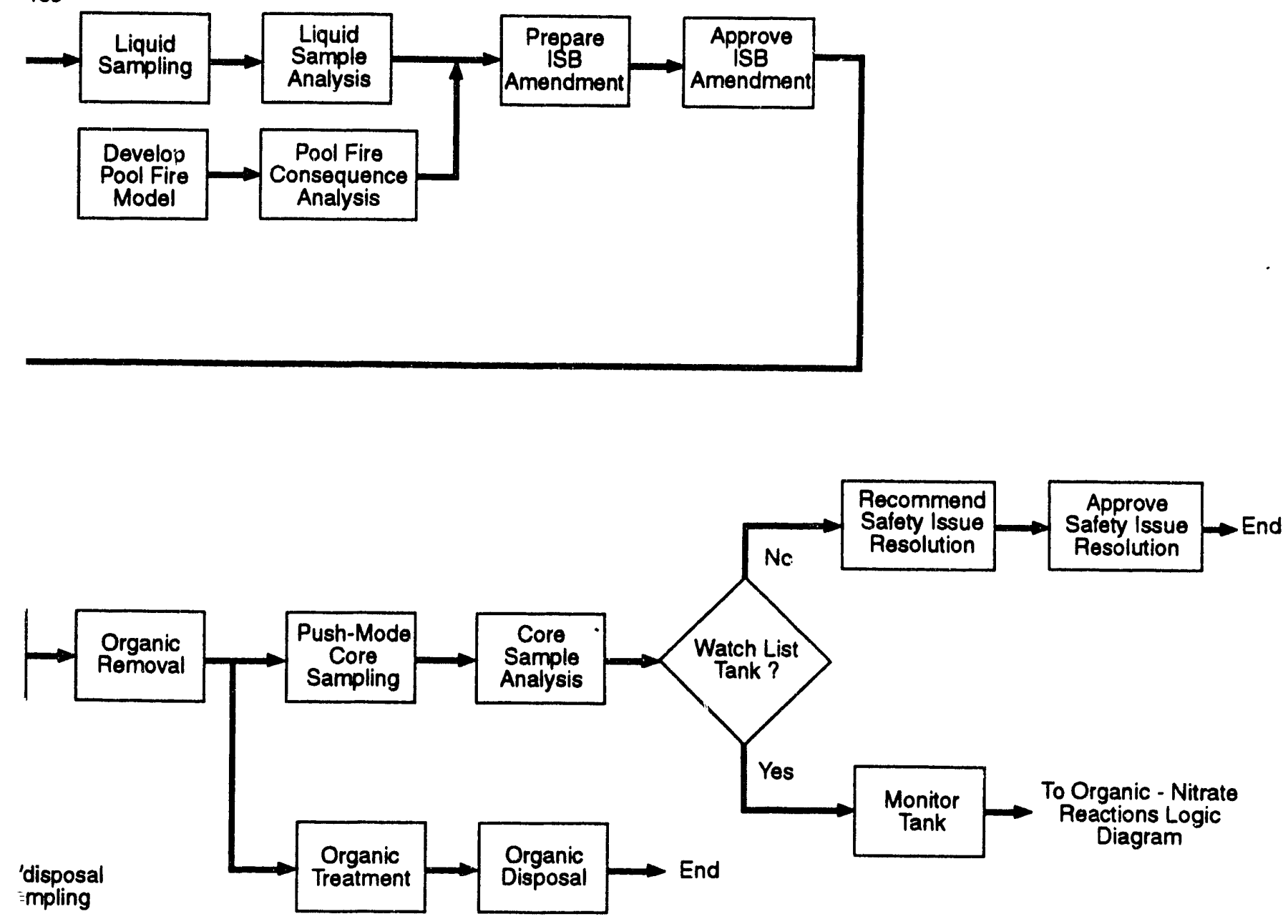


\section{Figure \\ Interim Safety Basis Surface Fires in Tanks that Fo}

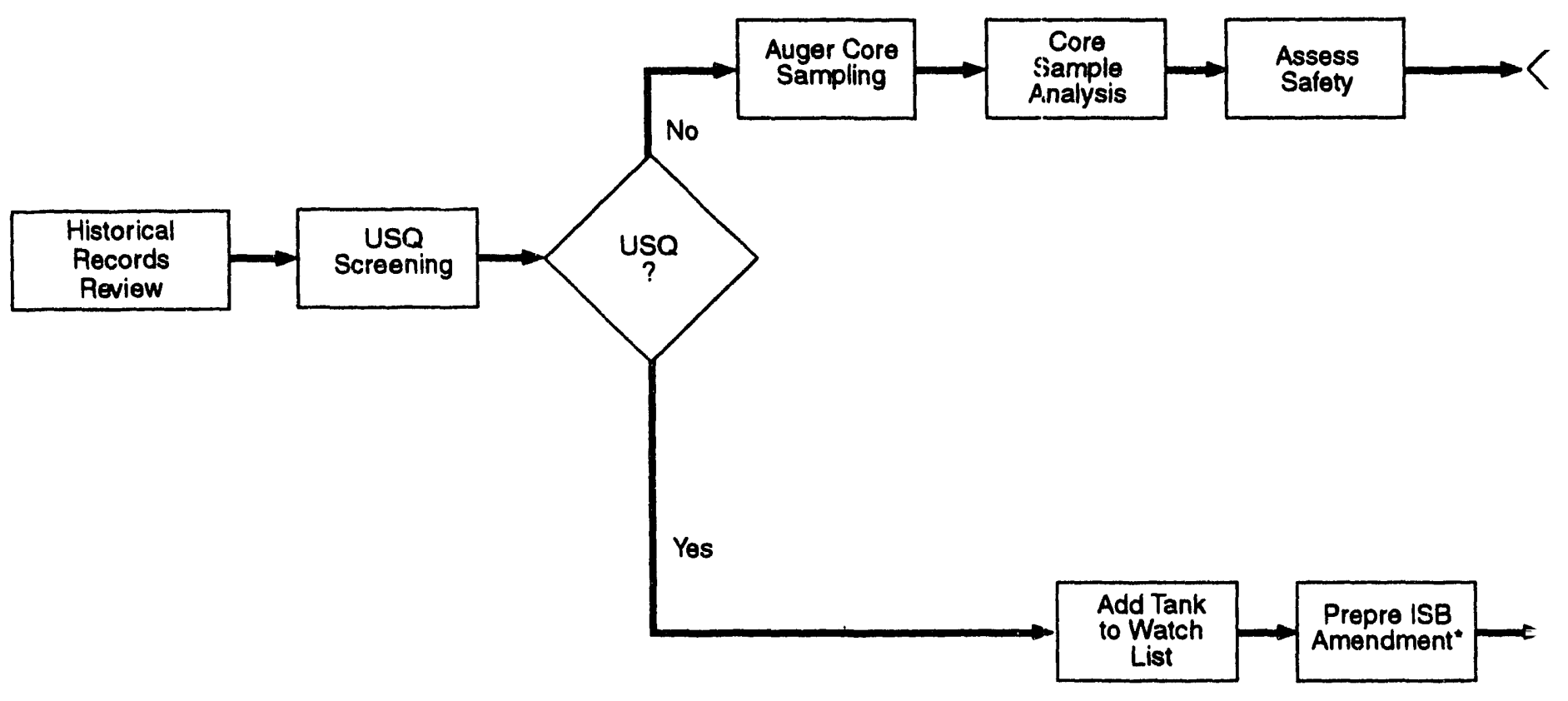

- To conduct vapor sampling, instalVop exhauster and to conduct auger cores

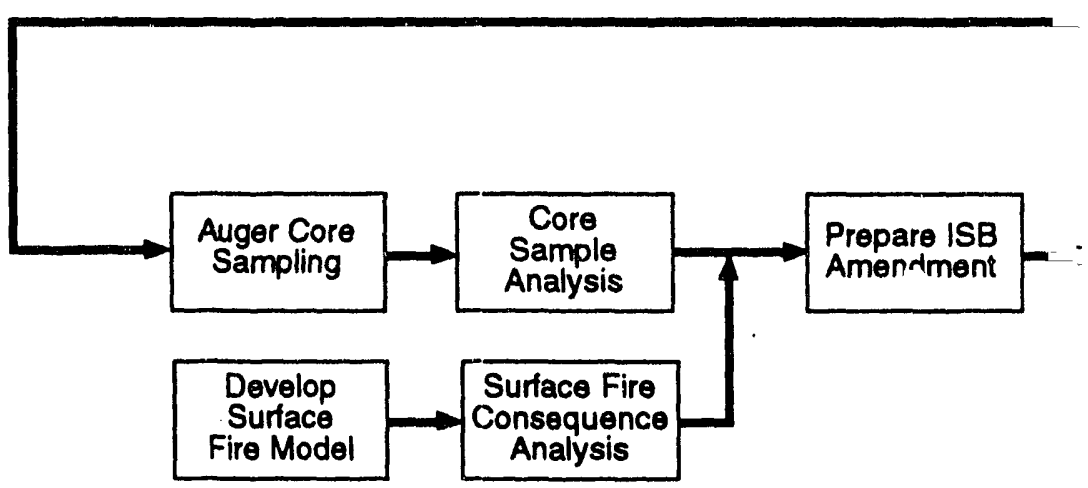

Note: Applicable to Also applicab discovered to 
Figure

\section{Interim Safety Basis Organic - Nitre}

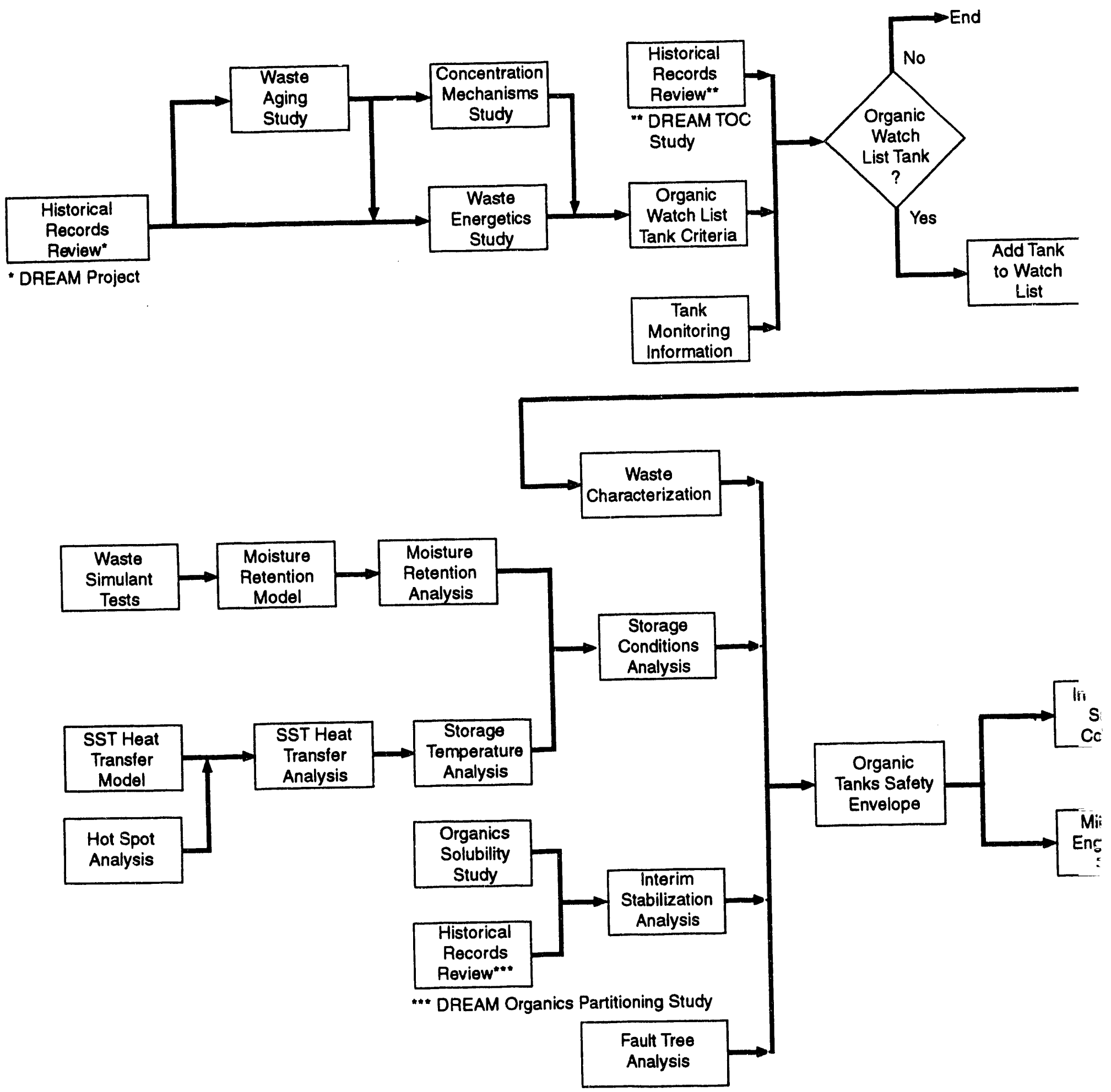




\section{Document (Draft)}

te Reactions

Note: Applicable to all SSTs on

Organic Tanks Watch List

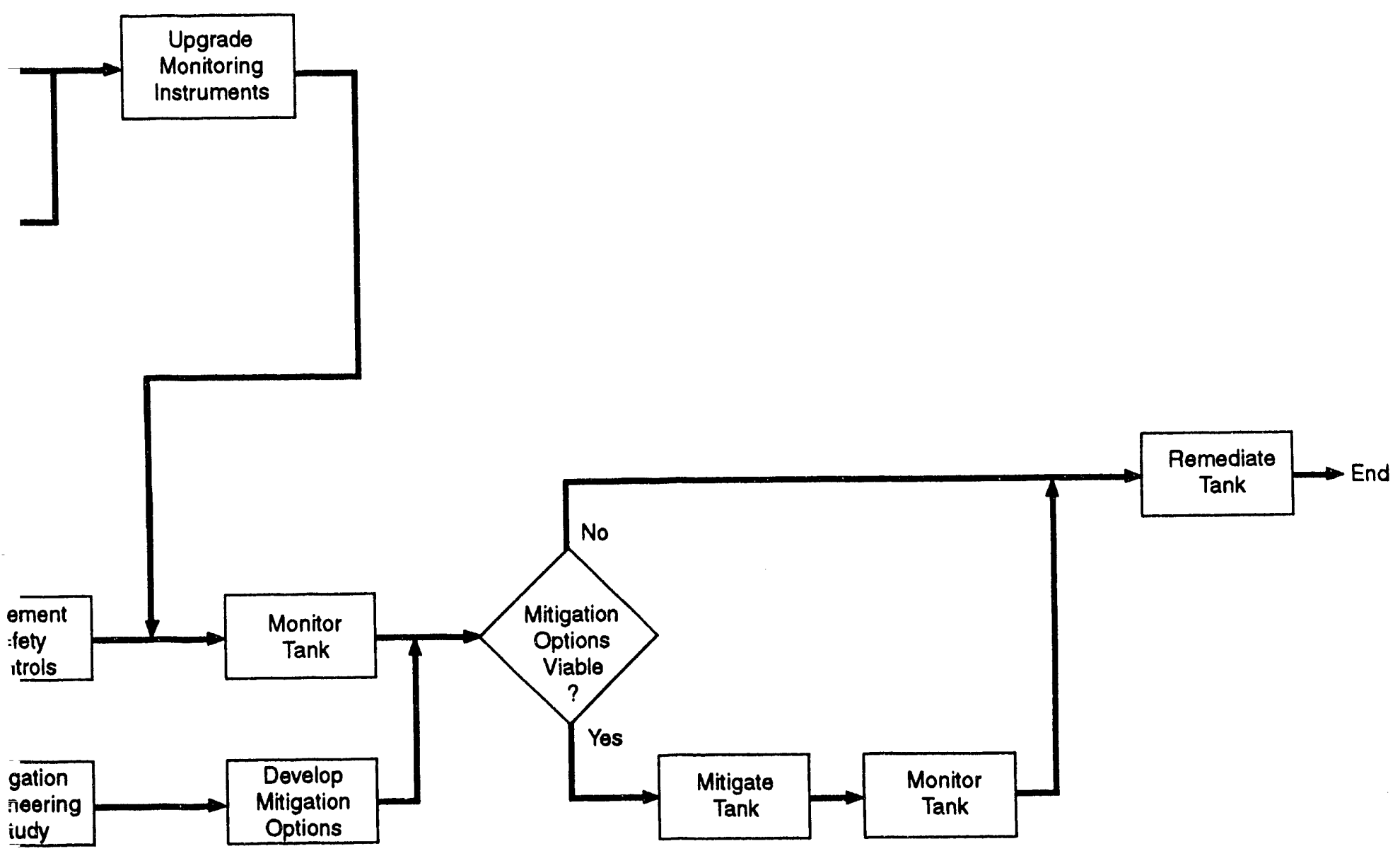


organic layer and underlying aqueous solution will be retrieved and analyzed. The analytical results will provide key information for an ISB amendment. Appropriate safety controls will be implemented to ensure safe interim storage until mitigation, and closure of the USQ will be recommended. Mitigation of the tank 241-C-103 safety issue will include removal and disposal of the floating organic layer. The tank will be resampled to determine if it is a candidate for removal from the organic tanks watch List.

\subsection{SURFACE FIRES IN TANKS THAT FORMERLY HELD ORGANIC LIQUIDS (FIGURE 13-3)}

The safety concern for tanks 241-C-102, 241-C-104, and 241-BY-112 (and any other SST determined to have contained organic liquids) is addressed in the Hanford Site Tank Farm Facilities Interim Safety Basis (WHC 1993):

"The issue of surface fires in tanks that formerly held organic liquids (e.g., Tank 241-C-102) should be revisited. The concern is that the upper surface of the waste may contain sait cake saturated with organic liquid, an admixture that may be easier to ignite than a liquid pool without wicks."

A USQ screening will be conducted based on information obtained from review of historical records. In the event of a negative finding, the tanks will be sampled to determine if they are candidates for the organic tanks Watch List. An affirmative USQ declaration will initiate activities directed toward USQ resolution. An ISB amendment will be prepared, reviewed, and approved to prepare for waste sampling. The analytical results will be used to assess tank safety. Appropriate safety controls will be implemented to ensure safe storage until mitigation, and closure of the USQ will be recommended. Mitigation activities will be conducted as part of the Program which addresses tanks with the potential for organic-nitrate reactions.

\subsection{ORGANIC-NITRATE REACTIONS (FIGURE 13-4)}

The safety concern relates to the potential for a propagating organic-nitrate reaction at waste temperatures above approximately $180{ }^{\circ} \mathrm{C}$ $\left(356{ }^{\circ} \mathrm{F}\right)$. A USQ screening was conducted for SSTs containing high concentrations of organic chemicals. It was concluded that a USQ does not exist. Therefore, the focus of the Program is directed toward resolution of the safety issue. The near-term (FY 1994 - FY 1996) program objective is to develop the information required to achieve the following:

- Characterize the chemical/physical properties of the waste

- Develop organic Watch List tank criteria supported by Taboratory testing, including actual waste samples

- Assess SST storage conditions, particularly, waste temperatures and moisture contents

- Assess the safety of interim stabilizing organic Watch List tanks. 
Information developed in these four areas will be used to develop an organic tanks safety envelope that bounds safe interim storage conditions. Appropriate safety controls will be implemented to ensure safe interim storage until mitigation.

The long-term (FY 1997 - FY 2002) program objective is to develop and demonstrate one or more viable mitigation options. Mitigation activities will be completed in the FY 2002 - FY 2006 time frame. 
WHC-EP-0671

\subsection{SCHEDULE}

The current Program schedule is shown in Figure 14-1. The schedule milestones are those included in the Environmental Restoration and Waste Management Five Year Plan (FY 1995 - FY 1999) Activity Data Sheet RL-1110, entitled "Waste Tank Safety Programs," and dated May 11, 1993.

The schedule shown in Figure 14-1 will be updated before issuing the Waste Tank Organic Safety Program Plan. 
WHC-EP-0671

This page intentionally left blank. 


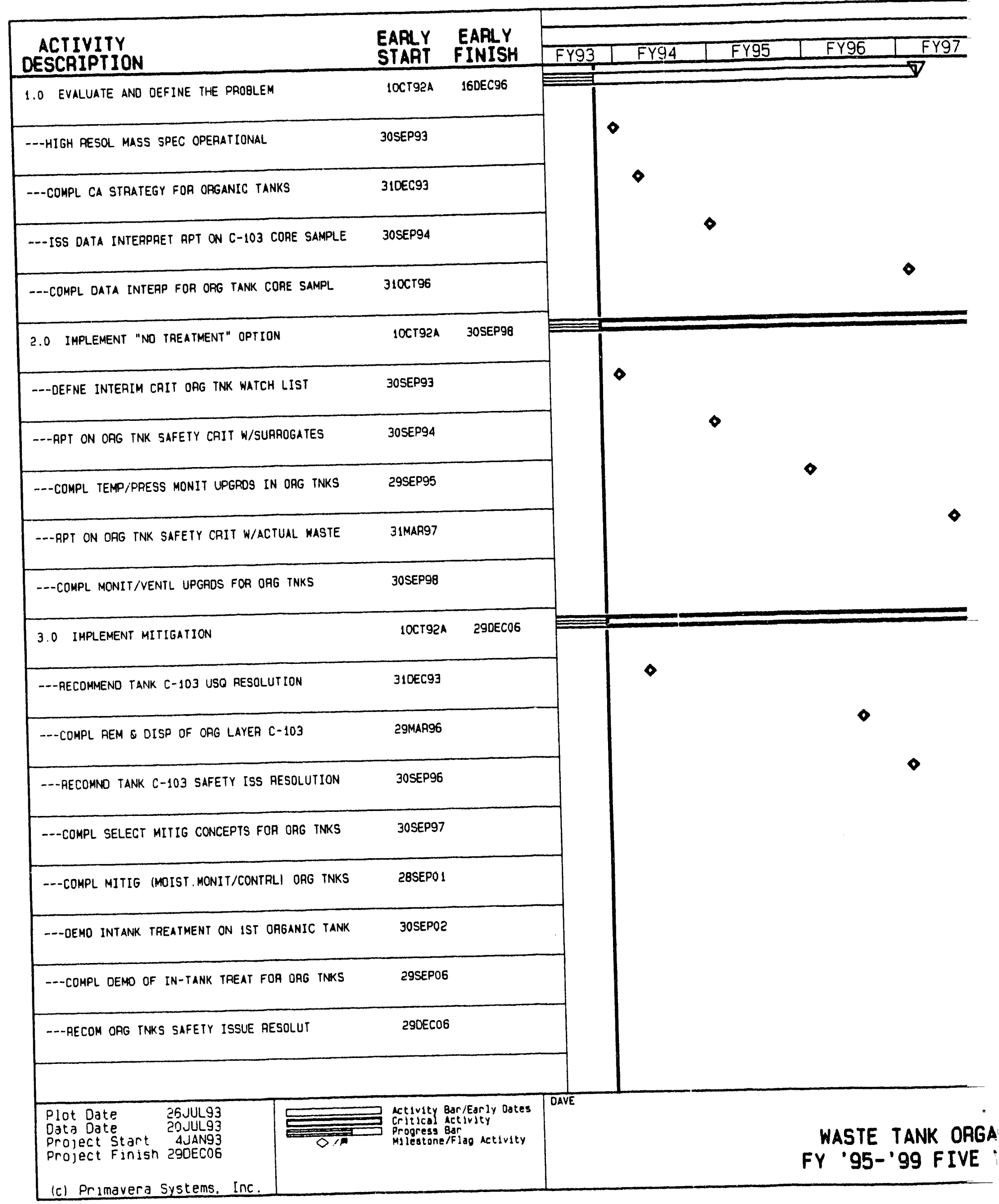


WHC-EP-0671 


\section{WHC-EP-0671}

\subsection{REFERENCES}

Babad, H., 1992, Program Plan for Evaluation and Resolution of the Organic Safety Issues in Hanford Site Waste Tanks, WHC-EP-0502, Westinghouse Hanford Company, Richland, Washington.

Reep, I. E., 1993, Status Report on Resolution of Waste Tank Safety Issues at the Hanford Site, WHC-EP-0600, Westinghouse Hanford Company, Richland, Washington.

WHC, 1993, Hanford Site Tank Farm Facilities Interin Safety Basis, WHC-SD-WM-ISB-001, Vol. 1, Rev. 0, Westinghouse Hanford Company, Richl and, Washington. 
WHC-EP-0671

This page intentionally left blank. 
WHC-EP-0671

\section{APPENDIX}

This Appendix is taken directly from WHC draft document, Program Plan for Evaluation and Resolution of the Orqanic Safety Issues in Hanford Site Waste Tanks, WHC-EP-0502. 
WHC-EP-0671

This page intentionally left blank.

APP-i $i$ 


\section{APPENDIX}

\subsection{DRIVERS}

Several requirements, or drivers, for conducting activities in the Organic Program have been identified and are briefly summarized below. These requirements (1aws, codes, regulations, orders) provide the bas is for establishing program priorities and the technical criteria for completing program activities.

\subsubsection{Safety Measures Law}

Waste tank safety is a primary safety concern within the DOE complex. Concern for waste tank safety at the Hanford Site was sufficient to compel the U.S. Congress to pass Public Law 101-510, Section 3137, Safety Measures for Waste Tanks at Hanford Nuclear Reservation (the Safety Measures Law). This law requires the following actions:

- Identify tanks that "may have a serious potential for release of high-level waste due to uncontrolled increases in temperature or pressure."

- Ensure that "continuous monitoring to detect a release or excessive temperature or pressure" is being carried out.

- Develop "action plans to respond to excessive temperature or pressure or a release from any tank identified."

- Restrict additions of high-level nuclear waste to the identified tanks unless no safer alternative exists, or until the serious potential for a release of high-level nuclear waste is no longer a threat.

- Report "on actions taken to promote tank safety, including actions specifically taken pursuant to this section of the law, and the ... timetable for resolving the outstanding issues on how to handle the waste in such tanks."

Waste Tank Safety Programs is the key element in responding to this law.

\subsubsection{Atomic Energy Act of 1954}

The following DOE orders are major drivers. The orders involve the management of waste containing radioactivity for the DOE under the Atomic Energy Act of 1954, as amended by Public Law 83-703.

- DOE Order 5820.2A, Radioactive Waste Management (DOE 1988)

- DOE Order 5480.1B, Environmental, Safety, and Health Prograll for Department of Energy Operations (DOE 1986a) 
WHC-EP-0671

[Taken from WHC-EP-0502]

- DOE Order 5481.1B, Safety Analysis and Review System (DOE 1986b)

- DOE Order 5480.5, Safety of Nuclear Facilities (DOE 1986C)

- DOE Order 6430.1A, General Design Criteria (DOE 1989)

- DOE Order 5480.21, Unreviewed Safety Questions (DOE 1991).

\subsubsection{Code of Federal Regulations}

The following Federal regulations are drivers for Waste Tank Safety Programs:

- 10 CFR 962, "Radioactive Waste: Byproduct Material"

- 10 CFR 1021, "Department of Energy NEPA Implementing Procedures"

- 40 CFR 191, "Environmental Radiation Protection Standards for Management and Disposal of Spent Nuclear Fue1, High-Level and Transuranic Radioactive Wastes"

- 40 CFR 261, "Identification and Listing of Hazardous Waste"

- 40 CFR 262, "Standards Applicable to Generators of Hazardous Waste"

- 40 CFR 1500-1508, "Regulations for Implementing the Procedural Provisions of the National Environmental Policy Act."

\subsubsection{Unreviewed Safety Question}

In accordance with DOE Order 5480.21, Unreviewed Safety Questions (DOE 1991a), the issue of a separable organic phase in waste Tank 241-C-103 was declared a USQ on September 21, 1992 (see Appendix A). This USQ was declared because the existing Safety Analysis Reports (SARs) and other documentation establishing the safety boundary for SSTs do not adequately address conditions under which combustion of the floating organic layer may occur. Organic-nitrate (and/or nitrite) reactions were addressed in the SARs and were not considered credible in Hanford waste tanks under current storage conditions. However, a floating organic mixture under specific conditions could ignite and burn, thus causing excessive pressures that may damage the tank structure and/or its ventilation system and allow contaminating the environment.

Although efforts are underway to formulate a $p l a n$ to resolve the USQ, the plan is not yet complete. To allow operations on the tank in the meantime, a Justification for Continued Operations (JCO) was transmitted to DOE on October 23, 1993. The JCO is included in Appendix A.

There is a question as to the relationship between a tank having a USQ and being on the Watch List. These are separate issues, and having a USQ on a tank does not necessarily require that it be on the Watch List. The operative word in the term "Unreviewed Safety Question" is "unreviewed." The magnitude 
WHC-EP-0671

[Taken from WHC-EP-0502]

of the consequences of an event such as fire, high-efficiency particulate air (HEPA) filter failure, etc. is not the deciding factor in whether a USQ is declared; instead, the deciding factor is whether the event comes within the bounds of existing safety documentation. If it does, the event cannot be a USQ.

The usual sequence of steps leading to the declaration of a USQ is that an individual or group "discovers" a scenario that could have serious consequences. The scenario is examined to see if it is credible and not obviously documented in present SARs. If it is, a review committee determines whether the scenario is within the existing, and therefore "reviewed," safety envelope(s). If it is, there is no USQ. If not, a USQ is declared, and an in-depth analysis is made of the scenario and incorporated into the SAR. The USQ is then resolved.

On the other hand, a tank can be put on the Watch List because there is some probability the tank could undergo some exothermic event leading to significant release of radioactivity. For organic tanks, the criteria for putting a tank on the organic Watch List is that the tank contain greater than 3 wt\% TOC.

From the foregoing it can be concluded that since a USQ was declared for a floating organic layer in one SST, then in the future any tank discovered to have an organic layer would be included under that USQ, regardless of whether this tank is on the Watch List. Whether the tank were placed on the Watch List would depend on whether the tank contained more than 3 wt\% TOC.

\subsubsection{Washington State Administrative Codes}

Waste Tank Safety Programs activities must comply with the state of Washington Administrative Codes (WAC) with respect to managing dangerous waste. The specific regulation is WAC 173-303, Section 110, Dangerous Waste Regulations.

\subsubsection{Defense Nuclear Facilities Safety Board}

The Defense Nuclear Facilities Safety Board (DNFSB) was created to provide advice and formal recommendations to the President and the Secretary of Energy regarding public health and safety issues at DOE nuclear facilities. The DNFSB reviews operations, practices, and occurrences at DOE nuclear facilities and makes appropriate health and safety recommendations. In the event that any aspect of operations, practices, or occurrences reviewed by the DNFSB is determined to present an imminent or severe threat to public health or safety, the DNFSB transmits its recommendations directly to the President.

\subsubsection{Tri-Party Agreement}

The Hanford Federal Facility Agreement and Consent Order (Ecology et al. 1990) contains provisions governing the treatment, storage, and disposal of hazardous waste, including remedial and corrective action activities. 
WHC-EP-0671

[Taken from WHC-EP-0502]

This page intentionally left blank. 


\section{DISTRIBUTION}

\section{Number of Copies}

\section{$\frac{\text { ONSITE }}{2}$}

1

2

44
U.S. Department of Engergy. Richland Field Office

R. E. Gerton

R. F. Christensen

R3-72

Public Reading Room

Al-65

MACTEC

S. T. Murff

R3-82

Battelle Pacific Northwest Laboratories

R. M. Bean

B. M. Johnson, Jr.

PNL Technical Files

P8-08

$\mathrm{K} 1-78$

$\mathrm{K} 1-11$

Westinghouse Hanford Company

H. Babad

$\mathrm{R} 2-78$

C. Defigh-Price

K. A. Gasper

J. C. Fulton

D. A. Turner (15)

N. W. Kirch

G. A. Hanson

M. A. Islam

J. M. Grigsby

A. Postma

R. J. Cash

J. W. Osborne

G. D. Johnson

W. T. Alumkal

H. D. Harmon

E. P. Vodney

P. R. Praetorius

D. C. Board

C. J. Geier

J. 0 . Honeyman

J. D. Thompson

R. S. Popielarczyk

M. A. Cahill

S. E. H. Ard

Document Processing and Distribution (2)

Central Files

Information Release Administration (3)

R2-31

$\mathrm{R} 2-08$

R2-31

$\mathrm{R} 2-78$

R2-11

T3-03

H5-53

H4-62

H4-62

R2-78

S4-60

R2-78

R2 -52

R2-52

B3-50

G1-63

S1 -57

R2-50

B2-30

R1 -30

Rl-30

Gl-67

Rl-80

L8-15

L8-04

RI-08 

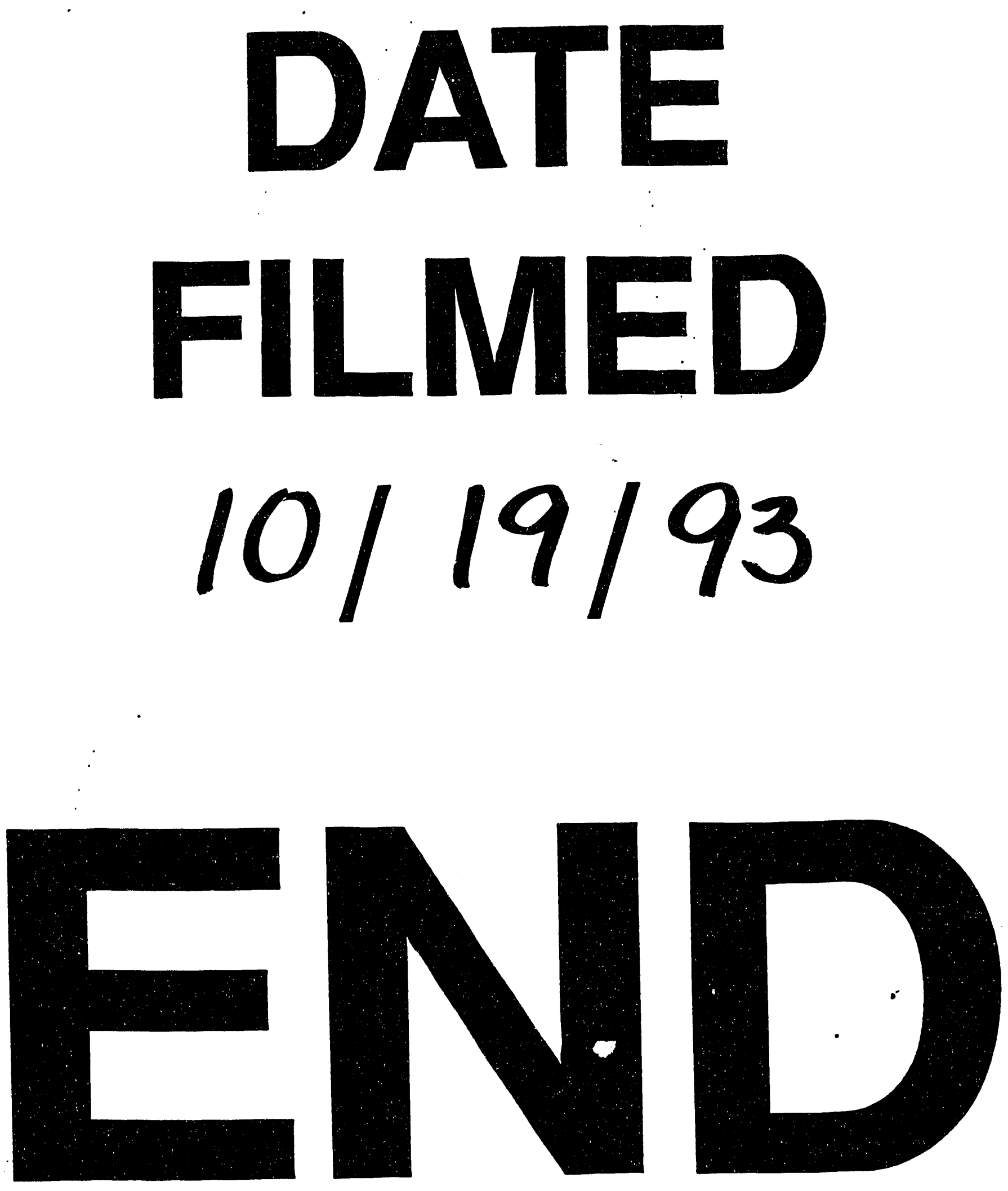
